\title{
Infeksi Larva Angiostrongylus cantonensis pada Keong Mas (Pomacea canaliculata) di Lima Desa Lingkar Kampus IPB Dramaga
}

\section{Infection of Angiostrongylus cantonensis Larvae in Golden Snails (Pomacea canaliculata) in Five Villages Surrounding Dramaga Campus of IPB University}

\author{
Risa Tiuria ${ }^{1 *}$, Sherly Noviara ${ }^{1}$ \\ ${ }^{1}$ Divisi Parasitologi dan Entomologi Kesehatan, Departemen Ilmu Penyakit Hewan dan Kesehatan Masyarakat \\ Veteriner, Institut Pertanian Bogor \\ *Corresponding author: risatiprio@gmail.com
}

\begin{abstract}
Abstrak
Keong mas (Pomacea canaliculata) adalah keong air tawar yang banyak dijumpai di area persawahan. Banyak masyarakat mengkonsumsi keong mas karena selain rasanya yang enak, keong mas juga memiliki kandungan protein yang cukup tinggi. Tujuan penelitian ini adalah untuk mengetahui persentase kecacingan nematoda pada keong mas. Angiostrongylus cantonensis adalah parasit nematoda zoonotik yang hidup pada keong mas dalam stadium larva infektif. Manusia terinfeksi A. cantonensis bila memakan keong mas yang terinfeksi larva infektif $A$. cantonensis dalam kondisi tidak matang. Studi cross-sectional digunakan dalam pengumpulan 150 ekor keong mas dari genangan air di sawah lima desa di sekitar Kampus IPB Dramaga. Hasil pengamatan menunjukkan persentase larva $A$. cantonensis yang terdapat pada keong mas sebesar $20 \%$ di Desa Cihideung Hilir, 16\% di Desa Cangkurawok, 6\% di Desa Ciapus, 3\% di Desa Suka Makmur dan 0\% di Desa Cinangneng. Perbedaan persentase keberadaan larva nematoda pada keong mas tampaknya sangat dipengaruhi oleh kondisi sanitasi lingkungan pada habitat keong mas. Hasil studi ini mengindikasikan bahwa terdapat ancaman infeksi cacing zoonotik pada masyarakat di kelima desa tersebut dan hal ini perlu mendapat perhatian dari sisi sanitasi dan hiegene lingkungan sebagai salah satu upaya pencegahannya.
\end{abstract}

Kata kunci: desa, lingkar kampus, keong mas, cacing zoonotik, Angiostrongylus cantonensis

\section{Abstract}

Golden snail (Pomacea canaliculata) is a freshwater snail which mostly live in rice field area. This snail is usually consumed by local people due to its tasty as well as high protein contain. The aim of this study was to know the percentage of nematode worms in golden snails. Angiostrongylus cantonensis is a zoonotic nematode lived in freshwater snail in the stadium form of infective larvae. Human was infected by this parasite when they consumed an undercooked snail-infected larvae. A cross-sectional study was performed to collected 150 freshwater snails from rice field from 5 villages surrounding Dramaga Campus of IPB University. Result of the study showed that percentage of the freshwater snail-infected larvae were $20 \%$ at Cihideung Hilir Village, $16 \%$ at Cangkurawok Village, 6\% at Ciapus Village, 3\% at Suka Makmur Village and 0\% at Cinangneng Village, respectivelly. The difference percentages of the freshwater snail-infected larvae on these 5 villages was seem due to the poor environmental sanitation and higene on the habitat of the water snails. Based on the present study we indicated that there is a zoonotic nematode threat to the peoples at these 5 villages, and as a consequece we have to pay more attention on this poor environmental condition in order to prevent infection.

Keywords: villages, surrounding campus, golden snail, zoonotic parasite, Angiostrongylus cantonensis

Received: 20 Juli 2020

Revised: 11 Agustus 2020

Accepted: 12 September 2020

\section{PENDAHULUAN}

Angiostrongylus spp adalah cacing nematoda parasit zoonotik Metastrongylid yang memiliki siklus hidup tidak langsung dengan peran tikus sebagai inang defintif, keong mas (Pomacea spp) sebagai inang antara dan manusia sebagai inang asidental (Bowman, 2014). Keong mas (Pomacea canaliculata) menyebar invasif pada banyak negara di Amerika Tengah, Amerika 
Selatan, Asia Timur, Asia Selatan dan Asia Tenggara. Keberadaan keong mas sangat berhubungan dengan rusaknya lahan pertanian khususnya tanaman padi di beberapa negara Asia Selatan, Jepang (Yang et al., 2013) dan juga Indonesia (Yunidawati, 2012). Keong mas disebut juga dengan keong murbei karena telur keong mas berkelompok dan berwarna merah muda seperti buah murbei yang menempel pada batang padi, batu, kayu dan sayuran (Budiyono, 2006).

Makanan keong mas dan sayuran yang disajikan dalam kondisi mentah atau setengah matang (undercooked) digemari oleh masyarakat di negara tertentu. Kandungan protein keong mas sebesar 16-50\% menjadikan keong mas sebagai bahan pangan sumber protein alternatif (Anggraini et al., 2018). Parasit nematoda zoonotik Angiostrongylus cantonensis adalah cacing parasitik yang dapat menginfeksi keong mas. Angiostrongyliasis pada manusia terjadi bila mengkonsumsi keong mas yang terinfeksi ataupun sayuran yang kena lendir keong mas terinfeksi dalam kondisi tidak matang (undercooked) (Komalamisra, 2009). Eosinophilik meningitis merupakan gejala spesifik Angiostrongyliasis pada manusia akibat makan keong mas terinfeksi yang undercooked. Kejadian eosinophilik meningitis telah dilaporkan terjadi di China, Amerika Latin dan beberapa di kepulauan Pasifik. Penyebaran penyakit zoonosis ini berkaitan dengan meningkatnya pariwisata, perdagangan dan keanekaragaman kuliner di negara tertentu. Penelitian di Jamaica menyebutkan bahwa cacing dewasa $A$. cantonensis pada sistem kardiopulmonari $22 \%$ tikus dan larva $A$. cantonensis pada $8 \% \quad P$. canaliculata mengakibatkan eosinophilik meningitis pada wisatawan yang makan salad di salah satu rumah makan (Lindo et al., 2002).

Prevalensi larva nematoda A. cantonensis pada keong mas belum pernah dilaporkan di Indonesia. Tujuan penelitian ini adalah untuk mengetahui persentase cacing nematoda pada keong mas. Pada penelitian ini dilakukan pengamatan kecacingan pada keong mas yang diambil dari area sawah di lima desa pada lima kecamatan lingkar Kampus IPB Dramaga.

\section{METODE PENELITIAN}

\section{Lokasi Penelitian}

Penelitian ini dilaksanakan di Laboratorium Helmintologi, Divisi Parasitologi dan Entomologi Kesehatan, Departemen Ilmu Penyakit Hewan dan Kesehatan Masyarakat Veteriner, Fakultas Kedokteran Hewan, Institut Pertanian Bogor.

\section{Rancangan Penelitian}

Rancangan cross-sectional digunakan dalam penelitian ini untuk pengumpulan $P$. canaliculata dari sawah di lima desa dari lima kecamatan lingkar Kampus IPB Dramaga. Sampel $P$. canaliculata berjumlah 150 buah diambil dari Desa Cangkurawok Kecamatan Dramaga, Desa Cihideung Hilir Kecamatan Ciampea, Desa Cinangneng Kecamatan Tenjolaya, Desa Suka Makmur Kecamatan Taman Sari dan Desa Ciapus Kecamatan Ciomas. $P$. canaliculata dikumpulkan selama empat hari. Sampel $P$. canaliculata diambil dari genangan air di sawah dan disimpan dalam akuarium di laboratorium agar bertahan hidup selama pemeriksaan.

\section{Prosedur Penelitian}

\section{Koleksi Larva Nematoda}

Pemeriksaan sampel $P$. canaliculata dilakukan untuk menghitung jumlah larva nematoda dalam tubuh $P$. canaliculata. Pemeriksaan dilakukan dengan membuka cangkang, lalu tubuh $P$. canaliculata dikeluarkan dan diletakkan pada cawan petri. Jarum pengait digunakan untuk mengeluarkan larva cacing dari tubuh $P$. canaliculata. Larva nematoda diletakkan dalam wadah yang berisi $\mathrm{NaCl}$ fisiologis dan disimpan dalam lemari pendingin bersuhu $4^{0} \mathrm{C}$ sebelum disimpan dalam botol berisi alkohol 70\% (Khairunnisa, 2007).

\section{Pewarnaan dan Identifikasi Larva Nematoda}

Pewarnaan semi permanen digunakan untuk larva nematoda (Khairunnisa, 2007). Penipisan 
lapisan kutikula dilakukan dengan larutan $\mathrm{KOH}$ $10 \%$ dan minyak cengkeh. Proses mounting dengan bahan perekat dilakukan setelah larva nematoda dimasukkan dalam alkohol bertingkat (70, 85 dan 95\%). Identifikasi larva nematoda berdasarkan pada biologi A. cantonensis (Maldonado et al., 2012; Cowie, 2011; Moreira et al., 2013).

\section{Analisis Data}

Data identifikasi larva nematoda pada $P$. canaliculata dianalisis secara deskriptif. Persentase larva nematoda dalam $P$. canaliculata dihitung dari jumlah $P$. canaliculata yang terinfeksi terhadap total $P$. canaliculata yang diperiksa.

\section{HASIL DAN PEMBAHASAN}

Larva nematoda yang ditemukan dalam tubuh $P$. canaliculata yang diperoleh dari desa sekitar Kampus IPB Dramaga memiliki bentuk tubuh filiform dengan bentuk anterior membulat. Morfologi bagian anteriornya terlihat bentuk seperti kenop (KT), esophagus, nervus ring dan lubang ekskretori (Gambar 1). Bentuk morfologi tersebut merupakan ciri khusus untuk larva nematoda A. cantonensis. Larva nematoda tersebut digolongkan dalam superfamili Metasrongyloidea dan famili Angiostrongylidae (Maldonado et al., 2012; Cowie, 2011; Moreira et al., 2013). Cacing dewasa hidup dalam arteri pulmonary tikus (Rattus rattus dan Rattus norvegicus), sehingga cacing dewasa nematoda ini dikenal dengan cacing paru-paru tikus (Simoes et al., 2011).

Dari kelima desa yang diamati, hanya 4 desa yang positif terdapat larva $A$. cantonensis. Persentase tertinggi $P$. canaliculata terinfeksi larva A.cantonensis berasal dari Desa Cihideung Hilir Kecamatan Ciampea, sedangkan persentase terendah $P$. canaliculata terinfeksi larva $A$. cantonensis berasal dari Desa Suka Makmur Kecamatan Taman Sari (Tabel 1). Lokasi sawah di Desa Cihideung Hilir Kecamatan Ciampea dan di Desa Cangkurawok Kecamatan Dramaga berdekatan dengan pemukiman penduduk serta adanya selokan yang berisi tumpukan sampah.
Lokasi sawah di Desa Ciapus Kecamatan Ciomas dan di Desa Suka Makmur Kecamatan Taman Sari tidak berdekatan dengan pemukiman penduduk namun terdapat tumpukan sampah sisa makanan di area genangan air di sawah. Sampah tidak banyak di temukan di Desa Cinangneng Kecamatan Tenjolaya dan juga lokasi sawah yang berada jauh dari pemukiman penduduk.

Habitat $P$. canaliculata adalah di kolam, sawah dan irigasi (Diratmaja dan Permadi, 2004). Siklus hidup $P$. canaliculata sangat tergantung pada temperatur, ketersediaan air dan makanan. $P$. canaliculata akan membenamkan diri dalam tanah yang lembab bila tidak ada air. Sanitasi dan higiene lingkungan area persawahan berpengaruh terhadap terjadinya infeksi nematoda A. cantonensis pada $P$. canaliculata (Cheng et al., 2011). Lingkungan yang penuh dengan sampah rumah tangga merupakan tempat yang sangat disukai tikus yang merupakan inang definitif dari A. cantonensis. Apabila tikus yang terinfeksi A. cantonensis mengeluarkan tinja di genangan air di sawah yang merupakan habitat $P$. canaliculata, maka telur infektif $A$. cantonensis akan teringesti oleh $P$. canaliculata. Telur infektif $A$. cantonensis akan berkembang menjadi larva infektif dalam tubuh $P$. canaliculata (Bowman, 2014).

Keberadaan larva $A$. cantonensis pada $P$. canaliculata tergantung pada sanitasi lingkungan area sawah dan pemukiman penduduk. Peluang $P$. canaliculata terinfeksi A. cantonensis akan lebih kecil apabila berada pada lingkungan area sawah yang bersih. A. cantonensis memperlihatkan spesifisitas yang luas bagi inang antaranya yaitu moluska air tawar yang terinfeksi alami, antara lain $P$. canaliculata, $P$. lineata, Achatina fulica dan Pomacea spp. (Thiengo et al., 2013).

Manusia yang mengkonsumsi $P$. canaliculata terinfeksi yang undercooked merupakan rute utama terjadinya infeksi $A$. cantonensis pada manusia. Sayuran yang terkena lendir $P$. canaliculata terinfeksi dan dikonsumsi mentah dapat juga menyebabkan Angiostrongyliasis pada manusia. Larva nematoda zoonosis A. cantonensis akan migrasi ke otak manusia yang menyebabkan eosinophilic 
Tabel 1. Persentase larva nematoda pada keong mas

\begin{tabular}{lccc}
\hline \multicolumn{1}{c}{ Desa, Kecamatan } & $\begin{array}{c}\text { Keong mas yang } \\
\text { diperiksa (ekor) }\end{array}$ & $\begin{array}{c}\text { Keong mas yang } \\
\text { positif (ekor) }\end{array}$ & $\begin{array}{c}\text { Persentase keong } \\
\text { mas yang positif (\%) }\end{array}$ \\
\hline Cihideung Hilir, Ciampea & 30 & 6 & 20 \\
Cangkurawok, Dramaga & 30 & 5 & 16 \\
Ciapus, Ciomas & 30 & 2 & 6 \\
Suka Makmur, Taman Sari & 30 & 1 & 3 \\
Cinangneng, Tenjolaya & 30 & 0 & 0 \\
\hline
\end{tabular}

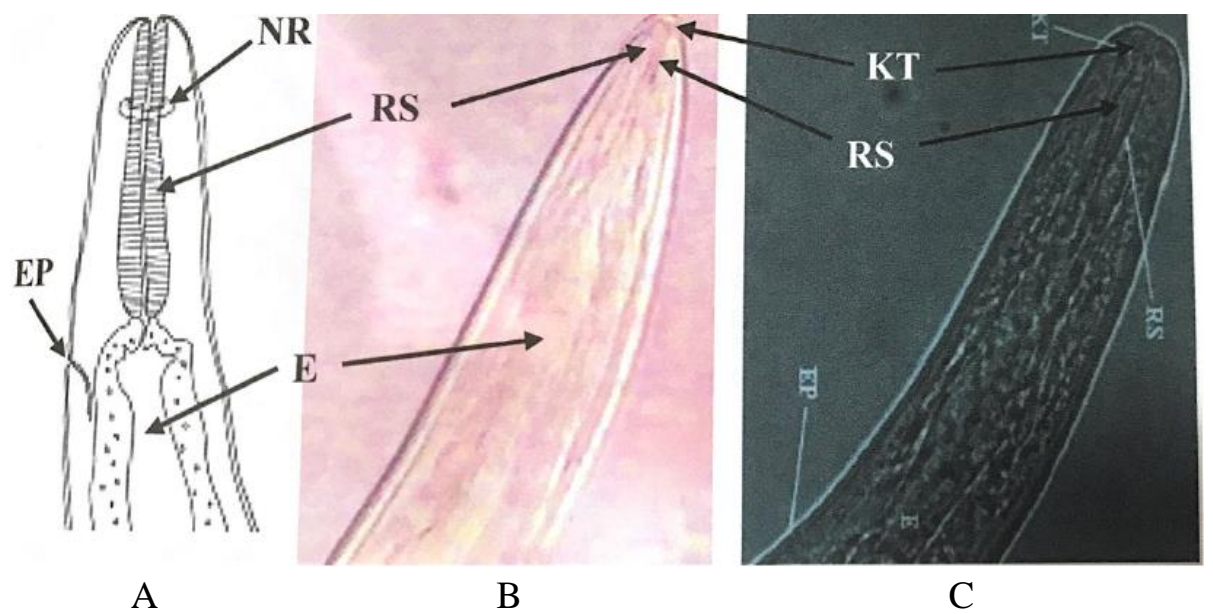

Gambar 1. Morfologi anterior larva nematoda hasil penelitian dan literatur. KT (bentuk seperti kenop); RS (Esophagus yang panjang); NR (Nervus Ring); EP (lubang ekskretori); E (saluran pencernaan). (A) Sumber dari Maldonado et al. (2012); (B) Larva nematoda hasil penelitian dengan pembesaran 10x; (C) sumber dari Cowie (2011)

meningitis dan ocular Angiostrongyliasis (Wang et al., 2011). Larva infektif $A$. cantonensis tidak akan melakukan migrasi lebih lanjut untuk melengkapi siklus hidupnya menjadi cacing dewasa pada manusia yang merupakan inang asidental. Umumnya infeksi oleh A. cantonensis tidak menyebabkan kematian inang asidental.

Eosinophilic meningitis adalah peradangan pada selaput otak (meningen) yang disertai dengan meningkatnya jumlah sel eosinofil akibat infeksi larva cacing A. cantonensis ( $\mathrm{Lv}$ et al., 2009). Gejalanya berupa sakit kepala yang hebat disertai dengan muntah, kekakuan leher dan paralisis wajah. Kejadian 8 dari 9 outbreak eosinophilik meningitis di China diakibatkan mengkonsumsi $P$. canaliculata terinfeksi yang mentah dan hanya 1 outbreak yang mengkonsumsi A. fulica terinfeksi mentah (Yang et al., 2013). China merupakan negara yang mempunyai prevalensi dan intensitas tinggi terhadap infeksi A. cantonensis. Keong mas disediakan sebagai makanan yang dapat dipesan pada rumah makan di China (Yang et al., 2013), hal ini berbeda dengan kuliner masyarakat di Louisiana yang tidak begitu menyukai $P$. maculata undercooked. Kejadian infeksi A. cantonensis pada $P$. maculata adalah sebesar $6.4 \%$ (9/140), akan tetapi jumlah kasus eosinophilik meningitis jarang terjadi di Louisiana, negara bagian dari Amerika Selatan (Teem et al., 2013).

Kasus eosinophilik meningitis belum dilaporkan di Indonesia hingga saat ini, walaupun banyak masyarakat lokal yang memanfaatkan hama tanaman padi ini sebagai bahan pangan dan pakan ternak (Rodiallah, 2018). Produk kuliner keong mas belum banyak terdapat di Indonesia, namun gizi yang tinggi dari daging keong mas dan dengan pengolahan yang benar, tidak mungkin keong mas menjadi kuliner alternatif (Apriyani, 2015). Edukasi sanitasi dan higiene lingkungan, menghindari konsumsi $P$. canaliculata undercooked dan sayuran mentah merupakan tindakan pencegahan untuk mengatasi penyebaran penyakit zoonosis Angiostrongyliasis. 


\section{KESIMPULAN}

P. canaliculata yang terinfeksi larva $A$. cantonensis terdapat di empat desa Lingkar Kampus IPB Dramaga. Persentase $P$. canaliculata yang terinfeksi larva A. cantonensis sebesar 20\% di Desa Cihideung Hilir, 16\% di Desa Cangkurawok, 6\% di Desa Ciapus dan 3\% di Desa Suka Makmur. P. canaliculata di Desa Cinangneng Kecamatan Tenjolaya tidak terdapat infeksi larva A. cantonensis.

\section{UCAPAN TERIMA KASIH}

Penulis mengucapkan terima kasih kepada Laboratorium Helminthologi, Divisi Parasitologi dan Entomologi Kesehatan, Departemen Ilmu Penyakit dan Kesehatan Masyarakat Veteriner yang telah memberikan fasilitas pada pelaksanaan penelitian ini.

\section{DAFTAR PUSTAKA}

Anggraini, W., Abidin, Z., Waspodo, S. 2018. Pengaruh Pemberian Pakan Keong Mas Terhadap Pertumbuhan dan Kelangsungan Hidup Lobster Pasir (Panulirus homarus). Jurnal Perikanan, 8(2), 20-29.

Apriyani, Widyastuti, I., Syafutri, M.I. 2015. Karakteristik Fisik, Kimia dan Sensoris Kerupuk Keong Mas (Pomacea canaliculata). Fistech - Jurnal Tekhnologi Hasil Perikanan, 4(1), 16-28.

Budiyono, S. 2006. Tekhnik Mengendalikan Keong Mas Pada Tanaman Padi. Jurnal Ilmu-Ilmu Pertanian, 2(2), 128-133.

Bowman, D.D. 2014. Parasitology For Veterinarians. $10^{\text {th }}$ Edition. Elsevier, pp: 186-188.

Cheng, Y.Z., Hou, J., He, X.H., Hong, Z.K., Li, L.S., Lin G.H., Chen M.X., Chen S.H.. 2011. Prevalence of Paragonimus and Angiostrongylus cantonensis infections in snails in Southeastern China. J. Anim. Vet. Adv., 10(19), 2599 - 2602.

Cowie, R.H. 2011. Biology: Taxonomy, Identification and life Cycle of Angiostrongylus cantonensis. Hawai (US): Pacific Biosciences Research Center University of Hawai.

Diratmaja, Permadi, K. 2004. Tingkat Serangan Keong Mas (Pomacea canaliculata) pada Padi Sawah. Jurnal Agrivigor, 4(1), 35-39.

Khairunnisa. 2007. Minyak cengkeh (Eugenia aromatica) dan Kalium Hidroksida 10\% Sebagai Bahan Pewarna Semi Permanen Pada Cacing Nematoda dan Acanthocephala ikan air laut. [Skripsi] Institut Pertanian Bogor.

Komalamisra, C., Nuamtanong, S., Dekumyou, P. 2009. Pila Ampullacea and Pomacea canaliculata as New Paratenic Hosts of Gnathostoma spinigerum. Southest As. J. Trop. Med. Pub. Health, 40(2), 243-246.

Lindo, J.F., Waugh, C., Hall, J., Myrie, C.C., Ashley, D., Eberhard, M.L., Sullivan, J.J., Bishop, H.S., Robinson, D.G., Robinson, T.H.D. 2002. Enzootic Angiostrongylus cantonensis in Rats and Snails after an Outbreak of Human Eosinophlic Meningitis, Jamaica. Emerg. Infect. Dis., 8(3), 324-326.

Lv, S., Zhang, Y., Liu, H.X., Zhang, C.W., Stermann, P., Zhou, X.N., Vtzinger, J. 2009. Angiostrongylus cantonensis: Morphological and Behavioral Investigation Within the Freshwater Snail Pomacea canaliculata. Parasitol. Res., 104, 13511359.

Maldonado, A.J., Simoes, R., Thiengo, S. 2012. Angostrongyliasis in the Americas, Zoonosis. Rio de Janeiro (BR) : InTech.

Moreira, V.L.C., Giese, E.G., Melo, F.T.V., Simoes, R.O., Thiengo, S.C., Maldonado Jr., 
A., Santos, J.N. 2013. Endemic Angiostrongyliasis in the Brazilian Amazon: Natural Parasitism of Angiostrongyliasis in Rattus rattus and $R$. norvegicus, and Sympatric Giant African Land Snails, Achatina fulica. Acta Trop., 125, 90-97.

Rodiallah, M., Yendraliza, Siregar, S. 2018. Performa Ayam Broiler Fase Starter Yang Diberi Tepung Keong Mas (Pomacea spp) Dalam Ransum Standar Komersial. Jurnal Peternakan, 15(1), 15-21.

Simoes, R.O., Monteiro, F.A., Sanchez, E., Thiengo, S.C., Garcia, J.S., Costa-Neto, S.F., Maldonado Jr, A. 2011. Endemic Angiostrongyliasis, Rio de Janeiro, Brazil. Emerg. Infect. Dis., 6, 1331-1333.

Teem, J.L., Qvarnstrom, Y., Bishop, H.S., Silva, A.J., Carter, J., Mclean, J.W., Smith, T. 2013. The Occurrence of the Rat Lungworm, Angiostrongylus cantonensis, in Nonindigenous Snails in the Gulf of Mexico Region of the United States. Hawai'I J. Med. Pub. Health, 72(6 Suppl 2), 11-14.
Thiengo, S.C., Simoes, R.O., Fernandez, M.A., Junior, A.M. 2013. Angiostrongylus cantonensis and Rat Lungworm Disease in Brazil. Hawai'I J. Med. Pub. Health, 72(6 Suppl 2), 12-18.

Wang, Q.P., Chen, X.G., Lun, Z.R. 2007. Invasive Freshwater Snail, China. Emerging Infectious Disease. www.cdc.gov/eid. 13(7).

Yang, T.B., Wu, Z.D., Lun, Z.R. 2013. The Apple Snail (Pomacea canaliculata), a Novel Vector of the Rat Lungworm, Angiostrongylus cantonensis: its Introduction, Spread and Control in China. Hawai'I J. Med. Pub. Health, 72(6 Suppl 2), 23-25.

Yunidawati. 2012. Pengendalian Hama Keong Mas (Pomacea canaliculata) dengan ekstrak biji pinang pada tanaman padi. [Tesis] Universitas Sumatera Utara. 